\title{
Анализ видового разнообразия древесно-кустарниковой растительности урбанофлоры города Костанай
}

\section{Analysis of species diversity of tree and shrub vegetation of Kostanay city urban flora}

\author{
Кобланова С. А., Төлеміс Ж. С. \\ Koblanova S. A., Tolemis Zh. S. \\ Костанайский государственный университет им. А. Байтурсынова, г. Костанай, Казахстан. \\ E-mail: saule200707@inbox.ru; zhuldyz_ranetki@mail.ru \\ Kostanay State University n. a. A. Baitursynov, Kostanay, Kazakhstan
}

Peфepam. В статье представлены результаты анализа видового разнообразия древесно-кустарниковой растительности урбанофлоры и ее роль в благоустройстве новых жилых массивов города Костанай.

Ключевые слова. Биоразнообразие, вид, жизненные формы, озеленение, урбанофлора.

Summary. The article analyzes the species diversity of arboreal and shrubby vegetation of urban flora and its role in the improvement of new residential areas of Kostanay.

Key words. Greening, species, life forms, species diversity, urban flora.

\section{Введение}

Городская среда представляет собой комплекс природных, природно-антропогенных и социально-экономических факторов, оказывающих большое воздействие на население. Города, в которых живет основная часть жителей планеты, призваны удовлетворять их потребностям и обеспечивать достаточно высокое, экологически обоснованное качество городской среды. Но вместе с тем они являются центрами возникновения основных экологических проблем. С развитием промышленности и урбанизации городов огромное значение приобретают объекты озеленения. К их числу относятся парки и лесопарки, скверы, бульвары, сады, уличные посадки, озелененные участки возле домов, санитарно-защитные и зеленые зоны промышленных предприятий, школьных и дошкольных учреждений, высших учебных заведений и др. Обязательное требование к системе озеленения - равномерность и непрерывность. Основными целями их создания являются: санитарно-гигиеническая, рекреационная, структурно-планировочная, декоративно-художественная (Жумадилова, 2014).

К наиболее газоустойчивым видам растений для городской среды относятся - виды тополей, жимолости, и др. Влияние древесных и кустарниковых пород на снижение концентраций в воздухе токсичных газов происходит путем рассеивания этих газов в верхние слои атмосферы кронами деревьев. Различные породы растений характеризуется разной способностью защиты от шума (Муканов и др., 2010). Использование древесно-кустарниковых растений улучшает качества городской среды. С гибелью зеленых насаждений устраняется естественный фильтр, очищающий воздух, так как на листьях растений осаждаются различные токсичные вещества и поглощаются газообразные примеси (Шевченко, 2014).

\section{Объекты и методы исследований}

Объектом для изучения были выбраны древесно-кустарниковые растения, произрастающие на исследуемых ключевых участках - это территория Центрального городского парка, а также аллеи и скверы новых жилых массивов «Юбилейный» и «Аэропорт» города Костанай. 
Изучение проводились нами в период с мая по октябрь 2018 г. Основным методом исследования был маршрутно-рекогносцировочный. В результате полевых работ было собрано 380 гербарных листов. Материалом для анализа древесно-кустарниковых видов послужили собственные сборы и гербарные материалы, хранящиеся в Гербарии Костанайского государственного университета им. А. Байтурсынова. При определении растений использованы: «Флора Казахстана» (Павлов, 1956; Байтенов, 1999), «Определитель растений Средней Азии» (Ковалевский, 1972). Все названия видов выверены по сводке С. К. Черепанова (1995). Выделение экобиоморф проводилось согласно классификации И. Г. Серебрякова (1962).

\section{Результаты исследований}

Анализ видового разнообразия древесно-кустарниковой растительности урбанофлоры города Костанай на исследуемых участках, показал, что наибольшее число видов относятся к отделу Magnoliophyta (класc Magnoliopsida). Древесно-кустарниковые растения представлены 51 видами, которые относятся к 31 роду и 17 семействам (Павлов, 1956; Байтенов, 1999; Черепанов, 1995).

Соотношение по жизненным формам, показало, что древесных видов растений 27, что составляет 52,9 \% от общего числа. Преобладающими видами на исследуемых участках являются Pinus sylvestris L., Populus balsamifera L., Populus nigra L., Betula pendula L. и Acer negundo L. Другие виды древесно-кустарниковых растений представлены в значительно меньшей степени. Доля участия таких видов, как Tilia cordata Mill., Acer platanoides L., Picea abies L., Populus alba L. не велика. Кустарники представлены 24 видами, что составляет 47,1 \% от общего числа.

Таксономический анализ древесно-кустарниковой растительности урбанофлоры г. Костанай на исследуемых участках, позволил выделить 8 ведущих семейств (по наибольшему числу видов - 40). Наибольшее количество видов относится к семейству Rosaceae - 15 видов, что составляет $29,4 \%$ от общего количества, семейство Salicaceae включает - 7 видов, что составляет $13,7 \%$, семейство Caprifoliaceae включает - 4 вида, что составляет 7,8 \%, семейства Pinaceae, Aceraceae, Oleaceae, Betulaceae - включают в себя по 3 вида, что составляет (5,9 \% для каждого), семейство Ulmaceae - 2 вида, что составляет 3,9 \% от общего числа. Остальные семейства Cupressaceae, Tiliaceae, Fagaceae, Fabaceae, Grossulariaceae, Verbenaceae, Adoxaceae включает в себе только по одному виду.

Анализ родов, выявил, что наибольшее количество видов относится к роду Salix L. - 4 вида, что составляет 12,9\% от общего количество видов, рода Populus L., Acer L., Ulmus L. включает в себя по 3 вида, что составляет (9,7 \% для каждого), род Betula L. включает в себя - 2 вида, что составляет $6,5 \%$, род Syringa L. - 2 вида (6,5\%), род - Malus sp. L. - 2 вида (6,5 \%), род Padus L. также включает в себя 2 вида, что составляет 6,5%. Рода Pinus L., Picea L., Tilia L., Larix L., Jniperus L., Quercus L., Fraxinus L., Elaeagnus L., Sorbus L., Aronia L., Physocarpa L., Sorbaria L., Caragana Lam., Ribes L., Lonicera L., Viburnum L., Sambucus L., Symforicarpos L., Berberis L., Callicarpa L. включает в себе по одному виду.

Таким образом, проведённый анализ видового разнообразия древесно-кустарниковых растений исследуемого района выявил, что наибольшее количество видов относятся к семейству Rosaceae и роду Salix, биоморфологический анализ показал, что доминируют древесные растения. На территории Центрального парка большое количество возрастных древесно-кустарниковых растений, а на участках новых жилых массивов «Аэропорт» и «Юбилейный» не большое видовое разнообразие как древесных, так и кустарниковых растений, в основном произрастают хвойные породы. Согласно правилам проектирования зеленых насаждений необходимо, чтобы от автотрассы древесные растения были отделены полосой кустарниковых растений. В определенных частях города такие посадки еще сохранились, но с каждым годом они сокращаются.

На территории города Костанай отмечено 3 вида древесных растений, включенных в 2006 г. в перечень редких и находящихся под угрозой исчезновения видов растений (Malus niedzwetzkyana Dieck., Quercus robur L., Lonicera tatarica L. (Петрова и др., 2017). Также, в работе Л. Я Шевченко (2014) отмечено произрастание видов - Quercus robur L., Syringa vulgaris L. На исследуемых нами ключевых участках данные виды встречаются, но очень редко, иногда в единичных экземплярах.

В настоящее время видовой ассортимент деревьев и кустарников урбанофлоры г. Костанай нуждается в видовом разнообразии. Ассортимент высаживаемых деревьев и кустарников можно расши- 
рить за счет таких пород как Populus alba L., Populus pyramidalis Rozier, Tilia cordata Mill., Quercus robur L., Amelanchier spicata Lam., Caragana arborescens Lam., Lonicera tatarica L., Physocarpus opulifolius (L.) Maxim., Berberis thunbergii DC., Populus balsamifera L., Malus pallasiana Jaz. L., Salix acutifolia L., Crataegus sanguinea Pall., Syringa josikaea J. Jacq. ex Rchb., Ulmus porvifolia Gelib., Ulmus lacvis Pall. и др.

Изучение видового разнообразия древесно-кустарниковой растительности урбанофлоры г. Костаная, выявило основные проблемы в области городского строительства. На сегодняшний день в связи с развитием новых жилых массивов г. Костаная необходимость в древесно-кустарниковых насаждениях увеличилась, так как они играют огромную роль для городской среды, создавая благоприятный микроклимат, регулируя тепловой и световой режимы, защищая жителей города от пыли, ветра и шума, сохраняя почвенный покров, создавая основу озелененных территорий - объектов повседневного отдыха жителей. По результатам изучения исследуемых участков города, особенно новых жилых массивов («Юбилейный» и «Аэропорт»), где повышена антропогенная нагрузка, рекомендуем производить озеленение более газоустойчивыми и пылеустойчивыми древесными-кустарниковыми видами.

Защитные свойства растений во многом зависят от тех экологических условий, в которых они находятся, поэтому важно тщательно подбирать видовой ассортимент древесных и кустарниковых растений для озеленения и благоустройства города с учетом рекомендаций и условий природно-географических зон.

\section{ЛИТЕРАТУРА}

Байтенов М. С. Флора Казахстана. - Алматы: Ғылым, 1999. - Т. 1. - 395 с.

Жумадилова А. Ж. Пылеудерживающая способность древесных и кустарниковых растений // Science News of Kazakhstan, 2014. URL: http://www.vestnik.nauka.kz/ (Дата обращения 05.04.2019)

Ковалевский С. С. Определитель растений Средней Азии. $-1972 .-145$ с.

Муканов Б. М., Майсупова Б. Ж., Шабалина М. В. Дендрология. - Алматы, 2010 - 121 с.

Павлов Н. В. Флора Казахстана. Т. 1. [Папоротники, Голосеменные, Злаки и др.]. - Алма-Ата, 1956. - 354 с.

Петрова Е. Ю., Третьякова А. С., Мухин В. A. Денрофлора города Костанай // Вестник Удмуртского университета, 2017. - С. 1-2.

Серебряков И. Г. Экологическая морфология растений. Жизненные формы покрытосеменных и хвойных. М., $1962 .-41 \mathrm{c}$.

Черепанов С. К. Сосудистые растения СССР (в пределах бывшего СССР). - СПб.: Мир и семья, 1995. - 992 с.

Шевченко Л. Я. Биоразнообразие древесно-кустарниковых пород, применяемых для озеленения города // Вестник Костанайского государственного педагогического института, 2014. - С. 191-192. 